\title{
Liability in Russian Corporate Law
}

\author{
By Vladimir Orlov
}

\begin{abstract}
Liability issues related to corporate activities are primarily regulated by general and special rules of the Civil Law in Russia that are mainly dispositive. The general liability rules consist of tort and contract liability provisions of the Civil Code. Special corporate norms are, in turn, included in the Civil Code provisions on juristic persons and legislation regulating corporate forms, and they concern liability of founders, shareholders and corporation as well as executives of corporation. The main form of civil liability is compensation for damages, the award for which generally requires that the illegal action and the caused damages as well as their causal relationship and the fault for causing the damages is proved in accordance with the rules on presumptions and burden of proof provided by the procedural rules. Traditionally, Russian civil liability rules have relied on the concept of illegality of an action (or breach of an obligation) that is to cause liability, which reflects the dominant role of legal supervision in the Russian legal system. However, in the event of liability of corporate executives, a breach of fiduciary duties could be regarded sufficient as a ground to qualify their actions as illegal without particular reference to concrete legal norms.
\end{abstract}

Keywords: Civil liability; Corporation; Corporate executives; Illegality

\section{Introduction}

The purpose of this paper is to present liability issues that are related to corporate activities in Russia. The terms "company" and "company law" are used here in the traditional sense to mean foundation and activities of the company, regardless the fact that, in Russia, the terms "corporation" and "corporate law", borrowed from the USA, are now in general use with the same meaning. In turn, the term "civil liability" is used in this article to cover the general civil law as well as the corporate law and obligation law norms that are to be applied where a company falls under liability.

In Russian law, liability issues related to corporate activities are primarily regulated by civil law norms, contained mainly in the first part of the Civil Code of $1994^{1}$. They include general civil law, corporate law $^{2}$ and obligation law rules. ${ }^{3}$

\footnotetext{
"Dr. of Legal Sciences; Professor, Herzen State Pedagogical University of Russia, Saint Petersburg, Russia and Adjunct Professor, University of Helsinki, Helsinki, Finland.

Email: vladimir.orlov@saunalahti.fi.

${ }^{1}$ The law no 51-FZ/1994, as lastly amended by the law no 251-FZ of 2020.

${ }^{2}$ Corporate law norms together with the other enterprise and company norms as a part of the Russian civil law are specific due to their dispositive dimension where the will expression plays a decisive role. I am ready to call such norms dispositively initiative or latently effective norms, since an expression of will of the party (parties) is required to activate the rules of such a norm, otherwise, no legal relation will be emerged, even in the event the norm contains the clear text.
} 
The purpose of corporate law ${ }^{4}$ norms is to regulate the internal relations of a company or the legal relations between a company and persons who are in close relationship to it. The external obligations of a company that are based on a contract or some other civil law ground, like causing damages or unjust enrichment, are in turn regulated by obligation law norms, among which are distinguished the rules that regulate obligations related to corporate activities. Special civil law obligations connected with entrepreneurship are not, however, recognised in the corporate law relations; therefore, they are subject to the application of general civil law provisions, including general and contract law rules.

Russian norms that regulate corporate activity are primarily legislative norms. However, value norms, due to which the discretionary power of judge has grown, have been generalised in present Russian civil law and, consequently, the significance of judicial practice as legal source has grown.

\section{Civil Liability in General}

In Russian civil law, the illegality of the breach of subjective civil law rights, causing damage and causal connection between the breach and damages as well as the fault of the violator are regarded as general requirements for the emergence of civil liability. These elements form an indispensable unity, or in other words, they are the constituent elements of civil law breach. The absence or incorrectness of any of these usually causes the exception of liability ${ }^{6}$. The general requirements for the emergence of civil liability correspond to the civil procedure law rules of Russian law. According to the provisions of the Russian Arbitration Procedure Code (2002) that regulate judicial proceedings for disputes between enterprises (companies), ${ }^{7}$ the party to the dispute ought to prove the facts, to which he refers in his arguments for supporting his demands and allegations, As applied to civil liability, this means, that, in order to obtain compensation for damages, the injured person must prove 1) the breach of obligation by the defendant, 2) the amount of

\footnotetext{
${ }^{3}$ In general, the judicial proceedings of civil law disputes (in particular, of companies), except for the corporate law cases, require, in accordance with the law (the laws no 45-FZ/2016 and no 47FZ/2016), that the plaintiff has presented his prejudicial settlement claim to the defendant. For more on the subject see, for instance, http://www.consultant.ru/document/cons_doc_LAW_358054/\#dst0 ${ }^{4}$ For more on the subject see Orlov (2015).

${ }^{5}$ Corporate activities are also subjected to the liability rules of the criminal and administrative law norms, and they concern company executives. Furthermore, corporate executives are subject to liability under the labour law norms. In general, the same act of the same person could be subject of different liabilities; thus, the civil law claims for damages are usually presented in criminal and administrative liability cases. For more on the subject see Tekutyev (2018) at 372-383 and Yarkovoy (2017).

${ }^{6}$ In present Russian civil law, there have been attempts to abolish the teachings on the constituent elements of the civil law breach, influenced by the teachings of criminal law, which was in a dominant position in the Soviet civil law.

${ }^{7}$ Russian Arbitration Procedure Code, art. 65.
} 
the damages that he suffered (including real damages and lost profits) and 3) the causal connection between the breach of obligation and the damage incurred. ${ }^{8}$

\section{Breach of Law or Illegality of Action}

Illegal behaviour is regarded in Russian law as the objective requirement of civil liability; in turn, the damage caused by a lawful action is not compensable in Russia, except for the cases provided by the law ${ }^{9}$. Illegal behaviour or civil law breach comprehends the act that causes prohibited consequences or damages ${ }^{10}$, provided that there is the causal connection between the breach and damage incurred by the fault of the violator.

Civil law breach comprehends both actions and omissions, and, in ordinary cases, they mean that the obligation is left unperformed improperly performed. ${ }^{11}$ The Civil Code knows now also the liability for misrepresentations ${ }^{12}$; in the cases related to enterprise activities as well as corporate relations the party that has provided false presentations may be liable even if he did not know about the falsity of his presentations. The Civil Code contains now also the liability rules on fault in contracting ${ }^{13}$.

Generally civil liability requires that behaviour violates the prescriptions that are contained in the legal norms. The question is, firstly, of the violation of prohibitions contained in the imperative legal norms. Important are also the dispositive legal norms that, although permit the deviations from their content, at the same make the provisions agreed by contractual parties obligatory. Also, the breach of the conditions of contract that are not contradictory to the prohibitions established by the law, or that are approved by the law, is regarded as illegal or as the breach of contract. Furthermore, attention is to be paid to that, according to the Civil Code ${ }^{14}$ the civil law rights and duties may arise also from contracts or

\footnotetext{
${ }^{8}$ According to the decision of the plenum of Russian supreme court no 7 of 24.March 2016, in order to obtain the compensation for damages, the following facts ought to be proven: 1) the act, action or decisions that has caused the compensation for damages liability, 2) the causal connection between the breach of obligation and the damage incurred, and 3) the amount of the compensatory damages. As to the fault, it is, in turn, impossible for the plaintiff to prove the fault of the obligation violator, since the question is of the mental attitude of the defendant to his action and its consequences. Therefore, the absence of fault belongs to the burden of proof of the defendant, thus, the fault of the obligation violator, the absence of which must be proven by the defendant, is presumed In Russian civil law. Moreover, the fact that the debtor has performed his obligations to lessen damages is also presumed, wherefore it is within the burden of proof of the creditor to prove that the debtor has not taken necessary measures to reduce damages. See http://www.consultant.ru/document/cons_doc_L AW_195783

${ }^{9}$ Russian Civil Code, art. 1064.3.

${ }^{10} \mathrm{Harm}$ caused by lawful action is subject to compensation in Russia only in the cases provided by the law.

${ }^{11}$ In general, the act, by which the obligation had been left unperformed or improperly performed, and, consequently, caused damage, is regarded as the breach of right. In such case, the burden of proof lies on the violator of obligation, and he must prove (credibly) that he had acted in accordance with the law.

${ }^{12}$ Russian Civil Code, art. $431^{2}$ as added by the law no 42-FZ of 2015.

${ }^{13} \mathrm{Ibid}$. at art, $434^{1}$ as added by the law no $42-\mathrm{FZ}$ of 2015.

${ }^{14}$ Ibid. at art. 8.1.
} 
transactions that, although not provided by the law, do not contradict it, or in other words, the binding effect of which is based on the basic principles of civil legislation, and the breach of the contract that is not contradictory to the basic principles and content of civil legislation is regarded in Russian law as illegal behaviour. But in the event that the law or the terms of the contract does not contain concrete prescription on the illegality of the behaviour in question, the civil liability is not to be applied.

\section{Compensatory Damages}

In general, damages comprehend in Russian civil law any lessening of personal or economic benefit. Damages may be material or immaterial. Material damages stand for the material losses, like the reduced value of the damaged thing, lessening or loss of the income, new expenses etc. Although the law favours compensation in kind, ${ }^{15}$ monetary compensation is quite common in corporate liability cases as well as in contractual and noncontractual relations. According to the general rules on damages of the Civil Code, ${ }^{16}$ the person whose right was violated may demand compensation for the damages caused to him. Thus, the civil liability is by its nature compensatory, and compensation for damages must correspond to the damages incurred. The full compensation for damages is the basic principle related to the civil liability in Russian civil law. ${ }^{17}$

\section{Causalty}

The imposition of compensation for damages in Russian civil law requires without exceptions that, there is a causal connection between the act of the right violator and the damages caused by him. This implies from the provisions of the Civil Code, that regulate the compensation for damages ${ }^{18}$, and the creditor's duty to compensate damages ${ }^{19}$ as well as the general grounds of liability for causing damages (harm) $)^{20}$. In the event, that the establishing of causal connections is difficult, the general scientific concepts of causal connection are followed. Or the cause and consequence relation is regarded as a kind of the objectively existing interdependence of phenomena, characteristic for which is that one requires the other. In a specific situation, the question is of two interdependent phenomena, one of which (cause) precede the other and give rise to this whereas the other (consequence) is always the result of the first phenomena. ${ }^{21}$ It is important, however, to notify that the jurisprudence deals with the social phenomena, where the cause and consequence connection is very difficult to simplify as one phenomenon being the mechanical or physical reaction to the other phenomenon,

\footnotetext{
${ }^{15}$ Ibid. at art. 1082 .

${ }^{16} \mathrm{Ibid}$. at art. 15.1 .

${ }^{17}$ The right to demand compensation for damages, as well the principle of full compensation, are presumed in Russian civil law.

${ }^{18}$ Russian Civil Code, art.15.1.

${ }^{19}$ Ibid. at art. 393.1.

${ }^{20} \mathrm{Ibid}$. at art. 1064.1.

${ }^{21}$ Grudtsyna (2008) at 560.
} 
particularly, if the question is of the human behaviour. So, because it is difficult in respect of social phenomena to concretise the reason that results as the concrete consequence, the legal practice is important. Just in the legal practice it is possible to choose from the totality of causes the juridically relevant causal connections, when, for instance, the liability could follow not only from the breach of the right but also from the omission of duties ${ }^{22}$. Just in the examining of a concrete case, it is often possible and necessary to evaluate the causal connection with reasonable level of veracity on the base of the proofs presented by the plaintiff, and, consequently, if the plaintiff would not in succeed in his proofs, the reasonable result of it is that the defendant is not liable. ${ }^{23}$

\section{Fault}

In Russian law, fault is generally regarded as a requirement of liability. The question is of the subjective requirement of liability, and it shows how the violator of right considers his illegal behaviour and its consequences. Ordinarily, particularly, if the question is of the civil liability, fault means that the violator starts his action, though he forecast the negative consequences of it, and he also knows how to avoid these. As a requirement for civil liability, fault is related to the compensation and restoration function of the civil liability ${ }^{24}$. Contrary to the criminal liability, the form of fault has seldom any juridical significance in respect of the civil liability. Usually any form of fault is sufficient, and in some cases, fault is not even regarded as a requirement for civil liability. And so, according to the Civil Code ${ }^{25}$, the law or a contract may require another liability ground (than fault). ${ }^{26}$

According to the general obligation law rule contained in the Article 401 of the Civil Code on liability, the liability for the violation of the obligation is grounded on fault (intent or negligence), unless other grounds are provided by the law or a contract. Generally, the guilt (fault) of the debtor is presumed, but in certain cases the burden of proof could be imposed on the creditor, as for instance, in the carriage. Furthermore, a condition (agreement) on eliminating or limiting

\footnotetext{
${ }^{22}$ However, in the event that the result of the behaviour, contradictory to the law, is only abstractly possible, the liability for such behaviour is accepted. Thus, the only concrete possibility and, in particular, the concrete consequence must be recognised as the causal relationship that causes liability,

${ }^{23}$ According to the Plenum decision of the Russian Supreme Court no 7 of 24 March .2016, the claim of the plaintiff ought to be rejected, if the court had not succeeded in establishing the causal relationships. See http://www.consultant.ru/document/cons_doc_LAW_195783/

${ }^{24}$ The purpose of fault in civil law is to serve as a condition for compensation of damages but not to be a measure of the amount of the compensatory damages.

${ }^{25}$ Russian Civil Code, art. 401.1.

${ }^{26}$ According to the general obligation law rule contained in the Article 401 of the Civil Code on liability, the liability for the violation of the obligation is grounded on fault (intent or negligence), unless other grounds are provided by the law or a contract. Generally, the guilt (fault) of the debtor is presumed, but in certain cases the burden of proof could be imposed on the creditor, as for instance, in the carriage. Furthermore, a condition (agreement) on eliminating or limiting the liability for an intentional violation of the obligation in advance is to be null and void.
} 
the liability for an intentional violation of the obligation in advance is to be null and void.

The rules on compensation for damages that concern the contract obligations connected with enterprise activities are distinguished from the general rules. So, unless otherwise provided by the law or a contract, the person who has left his obligation unperformed or improperly performed it, is, according to the Civil Code $^{27}$, liable, unless he proves that the proper performance became impossible due to force majeure, that is to say, extraordinary circumstances unavoidable in the given situation. Such circumstances do not include, in particular, the violations of obligations by contract partners of the debtor, the absence on the market of goods necessary for performance, nor the absence of the necessary monetary assets at the debtor's disposal. Thus, the civil liability related to the contract obligations connected with enterprise activities does not require fault, and is based on the risk share. Furthermore, the obligation parties, who are practicing enterprise activities, may agree on the indemnity clause concerning the compensation for the losses that are defined in their agreement, which are not connected with the obligation violation $^{28}$.

\section{Special Cases}

Civil liability in Russian civil law may be represented as shared, solidary or subsidiary in accordance with the criteria of the division of liability between several persons. They all are known in contract liability cases. Shared liability comprehends the case, where two or more persons are liable, and each of them is liable in an equal share to the creditor, unless the law or a contract provides otherwise. This liability rule is applicable according to the Civil Code in the event that the joint subjects are not subject to the application of the other liability rules, established by the law or a contract. ${ }^{29}$

Solidary liability is stricter than shared liability, and it ought to be based on the law or a contract; such liability is applicable in the case where the object of the unperformed obligation is indivisible. In accordance with the Civil Code rules that establish the grounds of solidary liability ${ }^{30}$, the solidary liability is, unless the law or a contract provides otherwise, presumed in respect of the breaches of the obligation that are related to enterprise activities. According to the Civil Code rules on the creditor's rights in the case of a solidary obligation, ${ }^{31}$ the injured party has the right to demand the performance (compensation) both from all the debtors jointly and from any one of them separately, and for all or for part of the debt. Thus, the injured party is entitled to demand the full compensation from the party who is able to pay. Unless otherwise following from the relations between the joint liable parties, the principle liable party, who has paid the full compensation or a part of it that is more than his share, has, in turn, the right of recourse (regress) to

\footnotetext{
${ }^{27}$ Ibid. at art. 401.

${ }^{28}$ Russian Civil Code, art. $406{ }^{1}$.

${ }^{29}$ Russian Civil Code, arts. 321, 1080 and 1081.2.

${ }^{30}$ See, for instance, Ibid. at art. 322.2.

${ }^{31}$ Ibid. at art. 323.
} 
the rest of the liable parties in equal shares, less his own share; in the event one of the liable parties becomes insolvent, his share is to be divided equally between the other liable parties. ${ }^{32}$

Subsidiary or additional liability comprehends that the person who is not the actual liability party is supplementarilly liable in accordance with the special provision of the Civil Code ${ }^{33}$. The person who is subject to the subsidiary liability is not necessarily the one who has participated in causing damage and usually he has not violated any obligation. The subsidiary liability becomes actualised in the case when the principle liable party refuses to satisfy the claims of the damages suffered party or this party has not received from the principle liable party in a reasonable time the answer to his claims. ${ }^{34}$ However, the creditor does not have the right to demand the satisfaction of his claim against the principal liable party from the person, who is subsidiarily liable, if this claim may be satisfied by way of setoff of a counterclaim against the principal liable party or by an indisputable recovery of the damages from the principal liable party. The person, who is subsidiarily liable, is obliged, before satisfying the claim, presented against him by the creditor, to warn about this the principal liable party, and if the claim has been filed against such a person, involves the principal liable party in participation in the case. Otherwise, the principal liable party is entitled to present against the claim of recourse of the subsidiarily liable person the objections that he had against the creditor.

From the cases of the subsidiary liability, the debtor liability for the actions of a third person is too distinguished in Russian civil law. Such liability is in question, when the debtor, in accordance with the Civil Code rules ${ }^{35}$, has imposed the performance of his obligation to a third party. In this case the third person is not in legal relation with the creditor, and, therefore, this is not entitled to present demands to him. According to the Civil Code rules ${ }^{36}$ that regulate the debtor's liability for actions of third persons, the debtor is liable if the performance of his obligation imposed to a third party has been left unperformed or performed improperly, it is the third person as the direct performer who is liable in such a case. The debtor's liability for actions of third persons as for his own actions naturally extends to the cases where he imposed the performance to a third person contrary to the prohibition established by the law or a contract. In such a case even simple transfer of the obligation shows the intentional breach of contract. In some

\footnotetext{
${ }^{32}$ Ibid. at art. 325.2.

${ }^{33} \mathrm{Ibid}$. at art. 399 . The rules are general by nature, wherefore the law may establish different order on the subsidiary liability.

${ }^{34}$ So, in the contract relations, the subsidiary liability ordinarily becomes actualised when the principle liable party has not satisfied the claims presented to him, regardless of the principle liable party's ability to pay. Contrary to the contract relations are noncontractual relations, for instance, in the case of bankruptcy of the juristic person, where the shareholder or other person in a dominant position in the company may become subsidiarity liable with the company for intentionally bringing the company into bankruptcy only in the event of insufficiency of its assets.

${ }^{35}$ Russian Civil Code, art. 313.1.

${ }^{36}$ Ibid. at art. 403.
} 
cases, the liability for actions of third persons is constructed from the principle culpa in eligendo ${ }^{37}$.

In the rules of the Civil Code on the debtor's liability for the actions of third person is recognised the possibility, that the third person, who is used by the creditor as the performer, is directly liable to the debtor ${ }^{38}$. This does not, however, mean that the creditor itself would be in that case released from the liability. In the event the creditor transfers the performance of his obligations to the third person, who is directly liable to the creditor, the contractual party (the debtor itself) and the third person (performer) are liable to the creditor, and it is up to him, to choose who the liability party is.

Recourse liability is related in Russian civil law to the cases regulated by the law, where the other person is liable for the actions of the other person ${ }^{39}$. The question is of cases of the vicarious liability and similar to it cases, like, for instance, recently presented the debtor's liability for actions of third persons. In the event, for instance, the employer or commercial organisation (enterprise) has become under the obligation to compensate damages caused by its employee or participant, it has the right to recourse to this person in the amount of the paid compensation, unless another amount is established by the law ${ }^{40}$. Recourse liability also concerns the solidary liability parties in respect of the debtor, who has performed the joint obligation in full. The Civil Code rules on the performance of a solidary obligation by one of the debtors provide ${ }^{41}$ that the debtor, who has performed the solidary obligation, has the right of recourse (regress) to the rest of the debtors in equal shares, less his own share, unless otherwise following from the relations between the joint debtors. ${ }^{42}$ Recourse claims are also in question in the rules on the rights of the surety, who has performed the obligation which provide that to the surety, who has performed the obligation, are to be transferred the creditor's rights related to the obligation ${ }^{43}$. The other Civil Code rules, where the recourse claims are mentioned, include the provisions on the repayment to the guarantor of the amounts paid under the independent guarantee ${ }^{44}$; they are to be paid in compliance with the terms of the independent guarantee, if not otherwise provided for by the agreement on the issuance of the guarantee.

The rules that concern joint liability in Russian civil law are closely related to the provisions of the Civil Code that regulate the creditor's fault (joint fault) ${ }^{45}$. According to the imperative rule of the provision, the court is to reduce the amount of liability of the debtor, if the obligation is left unperformed or performed improperly due to the fault of both parties. In this case, the question is not only of the intentional act of the debtor but also of his negligent omission, in the consequence of which the obligation became unperformed or performed

\footnotetext{
${ }^{37}$ For instance, the commission agent could be liable for choosing the third party as the performer.

${ }^{38}$ Ibid. at art. 403 .

${ }^{39}$ Russian Civil Code, arts. 402 and 403.

${ }^{40}$ Ibid. at arts. 1068 and 1081.1.

${ }^{41}$ Ibid. at art. 325.

${ }^{42} \mathrm{Ibid}$. at art. 325.2 .

${ }^{43} \mathrm{Ibid}$. at art. 365.1 .

${ }^{44} \mathrm{Ibid}$. at art. 379 as amended by the law no 42-FZ of 2015.

${ }^{45}$ Ibid. at art. 404.
} 
improperly. But in the event the creditor contributed intentionally or by negligence to the increase of the amount of damages caused by nonperformance or improper performance, or did not take measures to reduce it, the court has, according to the Civil Code ${ }^{46}$, only the right (but not duty) to reduce the amount of liability of the debtor. The rules of the Civil Code on joint liability are also applicable in the cases where the debtor, in accordance with the law or a contract, is liable for the nonperformance or improper performance regardless of his fault. ${ }^{47}$ Such cases include the obligations that are related to enterprise activities.

The rules of the Civil Code on joint liability are also applicable in the cases where the debtor, in accordance with the law or a contract, is liable for the nonperformance or improper performance regardless of his fault. ${ }^{48}$ Such cases include the obligations that are related to enterprise activities.

\section{Corporate Law Liability}

Corporate liability $^{49}$ is regulated in Russian law by the basic rules that are contained in the provisions of the Civil Code on juristic person ${ }^{50}$. Also, the main normative acts on the forms of company like the Joint Stock Company Law ${ }^{51}$ and the Limited liability Company Law ${ }^{52}$ contain corporate liability rules. In addition to the legislative acts, the internal bylaws of the companies are to be regarded as corporate law sources. Corporate liability norms, as corporate law norms in general, are mainly imperative or obligatory, but as being civil law norms, they contain a dispositive element in a sense that there is no body or person outside the corporation who may order to apply the corporate liability rules.

The concept of juristic person plays central role in the civil law regulation of enterprise activities, in particular, related to company liability in Russia. According to the Civil Code ${ }^{53}$, the juristic person is an organisation that has separate property and is liable with it for its obligations, it may in its own name acquire and exercise civil rights and bear civil duties and may be a plaintiff and defendant in court. ${ }^{54}$

\footnotetext{
${ }^{46}$ Ibid. at art. 404.1.

${ }^{47}$ Ibid. at art. 404.2.

${ }^{48}$ Ibid. at art. 404.2 .

${ }^{49}$ For more on the subject see Trofimov (2018); Borisov (2017); Popov, Popova (2012) at 70-73; Tekutyev (2018) at 332-354; Tselovalnikova (2018); and Stepanov (2018) at 2.

${ }^{50}$ Russian Civil Code, Chapter 4.

${ }^{51}$ Joint Stock Company Law (of 1995), arts.3, 6 and 71.

${ }^{52}$ Limited Lliability Company Law (of 1998), arts.3, 6 and 44.

${ }^{53}$ Russian Civil Code, art. 48.

${ }^{54}$ According to the Article 50 of the Civil Code, juristic persons in Russian law are distinguished into corporate and unitary entities as well as into commercial and non-commercial (non-profit) organizations. Commercial corporate entities include (general and limited) partnerships, business (limited liability) partnerships and companies as well as production cooperatives and farms. In turn, companies are distinguished into (public and non-public) joint stock companies and limited liability companies. The main purpose of commercial organizations is to practise enterprise activity, and their goal is deriving profits, whereas the enterprise activity of the non-profit organizations, such as consumer cooperatives, societal organizations, and foundations, must be connected with the objects of their primary activities.
} 
The legal position of juristic person is determined in accordance with its legal capacity and legal act capacity as well as liability capacity, the rules on which are based on the provisions of the law. ${ }^{55}$

The subjects of the corporate law liability are, firstly, the company and its participants, including the founders, since the liability of the company and its participants is differentiated. The corporate law liability concerns also the corporate executives, the directors and the members of the executive bodies of the company, each of which acts within the limits of its competence and is liable for its acts. The list of persons who may present corporate liability demands is also exclusive: only the corporation itself and its participants, as well as in certain cases its debtors and the subsidiary company and its shareholders (participants) have the right to demand compensation for damages in corporate law cases. The corporate law liability plays a reparative function, and the norms on it are dispositively initiative or latently effective, their application requires the initiative or expression of will of the injured party ${ }^{56}$.

\section{Liability of the Founders and Participants}

According to the Civil Code $^{57}$, the founder of (or a participant in) a juristic person (company) or the owner of its property is in general not liable for the obligations of the juristic person, as well as correspondingly juristic person is not liable for the obligations of the founder (participant) or the owner it, unless otherwise is provided by the law. However, the founders of the company are jointly and severally liable for obligations associated with the formation of the company and arising prior to its registration; this liability is based on the law, but those obligations may be transferred to the company on the approval of the general meeting of shareholders. ${ }^{58}$ Moreover, the members of the (limited liability) company bear jointly (solidarily) subsidiary liability for the obligations of the company to the extent of the value of the unpaid contributions 59.60

\footnotetext{
${ }^{55} \mathrm{Ibid}$. at art. 48.

${ }^{56}$ Contrary to the corporate law liability rules, the rules on criminal and administrative liability that concern corporate activities are of public law nature and consequently imperative. In general, characteristic for criminal liability are strict requirements of legality which also means that the application of the criminal liability rules is obligatory for the state; obligatory for the administrative officials are the administrative liability provisions. Also, the Labour Code contains the corresponding imperative provision: it imposes on the employer the obligation to direct to the director disciplinary measures, if he has violated the labour law norms.

${ }^{57}$ Ibid. at art. 56.2.

${ }^{58}$ Ibid. at art. 98.2 .

${ }^{59} \mathrm{Ibid}$. at art. 87.7.

${ }^{60}$ The participants (shareholders) of the company may conclude the corporate agreement on the execution of their corporate rights is simply a (general) civil law agreement. In accordance with the Civil Code $406^{1} .5$, it may include the indemnity clause (on the compensation for the losses that are defined in their agreement).
} 


\section{Liability of the Corporation}

In general, the juristic person (company), except for the institutions that are financed by the owner, are liable for their obligations with all their property ${ }^{61}$, but it is not liable for the obligations of the other persons. According to the Civil Code, the company may, in certain cases, fall under liability for the activities of the other company. This is the case of the liability which may arise for the company (partnership) in the subsidiary and principal relation that is regulated by the Civil Code $^{62}$ as well as the Joint Stock Company Law ${ }^{63}$ and Limited Liability Company Law $^{64}$. In the subsidiary and principal relation, the principal company can bear liability on the one hand for the acts (transactions) of the subsidiary company and on the other hand in the case of the insolvency (bankruptcy) of the latter.

The liability for the transactions of the subsidiary company presupposes that

- the principal company may, due to its prevailing share in the charter capital of the subsidiary company or in accordance with a contract between it and the principal company or otherwise determine its decisions

- that concern the acts (transactions) of the subsidiary company made by following the binding orders of the principal company or on the consent of this, and

- these acts (transactions) cause damages;

This liability is solidary (joint and several) and strict.

Contrary to this, the liability of the principal company for the debts of the subsidiary company, if this is brought into bankruptcy through the fault of the principal company, is subsidiary ${ }^{65}$ and presupposes that

- the principal company had the right or possibilities in accordance with its contract with and the charter of the subsidiary company to give binding orders to this,

- provided, however, that the principal company misused faulty his right or possibilities or it knew in advance that the consequence of its actions (the binding orders given to the subsidiary company) would be the bankruptcy of the subsidiary company. ${ }^{66}$

Besides the subsidiary company, its shareholders (participants) also have the right to demand that the principal company compensate the damages caused through its faults to the subsidiary company in accordance with the general rules of

\footnotetext{
${ }^{61} \mathrm{Ibid}$. at art. 56.

${ }^{62}$ Ibid. at art. 67.

${ }^{63}$ Joint Stock Company Law, arts. 3 and 6.

${ }^{64}$ Limited Liability Company Law, arts. 3 and 6.

${ }^{65}$ According to the Article 6.3 of the Joint Stock Company Law, the principal company shall be liable for bringing the subsidiary company into bankruptcy.

${ }^{66}$ Joint Stock Company Law, art. 6.3.
} 
the Civil Code on liability ${ }^{67}$, provided that the principal company knew in advance that the subsidiary company would incur losses as consequence of its actions. ${ }^{68}$

\section{Liability of the Persons in a Dominant Position}

With exception to the general corporate law rule on separate liability of the company and its participants (shareholders), the shareholder or other person in a dominant position in the company (including the controlling shareholders) may be subsidiarily liable with the company, however, only for bringing the company into bankruptcy and in the event of insufficiency of its assets provided that such a person has used his right or possibilities to give binding orders or otherwise determine the decisions of the company knowing in advance that the consequence of his actions would be the bankruptcy of the company. ${ }^{69}$

\section{Liability of the Corporate Executives}

According to the general provisions of the Civil Code on liability of the corporate executives, the person who by force of the law or of the juristic person's constituent document comes out on its behalf, or use the representative power in the name of the company is expected, according to the Civil Code ${ }^{70}$, to act in the interests of the juristic person it represents in good faith and reasonably). In case of non-observance of these as well as the customary requirements the representative of the juristic person is obliged, upon the demand of the juristic person, or the founders (the participants) acting on behalf of this, to compensate the damages caused by his fault ${ }^{71}$ taking into account ordinary business practices and risks, which ought to be proved ${ }^{72}$. $^{73}$ The same liability is extended also to the persons who may determine the actions of the juristic person ${ }^{74}$, as well as to the members of the collegiate executive body, except for those who voted against the adoption of the decision or did not take part in the voting concerning the issue ${ }^{75}$; in the event of jointly caused damages the liability is solidary ${ }^{76}$. The Civil Code ${ }^{77}$

\footnotetext{
${ }^{67}$ Russian Civil Code, art. 1064.

${ }^{68}$ Joint Stock Company Law, art. 6.3.

${ }^{69}$ Ibid. at art. 6.3.

${ }^{70}$ Russian Civil Code, art. 53.3.

${ }^{71}$ Ibid. at art. 53.

${ }^{72}$ Ibid. at art. 53.1.

${ }^{73}$ In Russian corporate law, the liability of the corporate executives is based on the concept of fiduciary duties developed at common law by following the rules on trust and agency institutions, and they comprehend duty of care and duty of loyalty that, in Russian legal practice, generally means a prohibition of the conflict between the personal interest of the company executive and the interest of the company, but sometimes also the bona fide behaviour or understanding of the meaning of own acts. Namely the behaviour that breaks personally imposed fiduciary duties may cause liability for damages. See for instance Stepanov (2018) at 2: and also https://www.litmir.me/ $\mathrm{bd} / ? \mathrm{~b}=628065$

${ }^{74}$ Russian Civil Code, art. 53.3. Thus, the rule of piercing the corporate veil is applicable in Russian corporate law.

${ }^{75} \mathrm{Ibid}$. at art. 53.2.

${ }^{76} \mathrm{Ibid}$. at art. 53.4.

${ }^{77}$ Ibid. at art. 53.5.
} 
expressly provides that an agreement on the restriction or elimination of the liability presented here is null and void. This concerns fraudulent acts and, in the event of public company, also unreasonable acts.

The liability of the members of the governing bodies of the company provided by the Joint Stock Company Law is also based on the general company law rules on liability of the Civil Code ${ }^{78}$ and means in general the liability for negligence. Under the article 71 of the Joint Stock Company Law, the members of the governing bodies are presupposed to act in good faith and reasonably, but on the other hand, in determining the grounds and extend of their liability, ordinary business practices and other relevant considerations must be taken into account. This liability is personal as well as solidary (joint and several), but the persons who did not take part in the administration (or voted against) is not to bear liability; in this case the company or shareholders owning not less than 1 percent of the common shares of the company have the right to apply to a court with a suit.

Characteristic for the liability of executives and representatives of company is, that their liability is to be realised simply at the moment when their duty, determined through the value concepts ${ }^{79}$, to act in good faith and reasonably is violated, provided that it has caused damages ${ }^{80}$, in which case it is not necessary to prove the violation of the concrete legal norm that is traditionally regarded as belonging to the constituent elements of the civil law breach. Thus, in the cases of the liability of executives and representatives, the facts that are to be proven include that:

- (fiduciary) duty to act in good faith and reasonably for the benefit of the company is violated, and

- it has caused damages, as well as that

- there is the causal connection between the breach and the damages incurred; and that

- The breach has been occurred intentionally ${ }^{81}$.

The person is regarded acted in good faith and reasonably, if he has not personal interests in respect of the decision to be made, if he has clarified exactly all the information that is necessary for the decision making, and if there are other circumstances that show the person acted for the benefit of the company. The director is regarded as acted in good faith and reasonably also, if he has executed all necessary and sufficient measures for the company achieve the aims imposed for the foundation of it, including the duties that are established by the public law. In turn, the director is not regarded acted in good faith, if there is a collision

\footnotetext{
${ }^{78}$ Ibid. at art. 53.3.

${ }^{79}$ The growing use of the value concepts and the value norms in Russian civil law indicates its development towards the growing role of the judicial discretion and consequently the approval of the significance of the judicial practice.

${ }^{80}$ The damages caused by the acts of the director are regarded as the requirement of the director's liability.

${ }^{81}$ Thus, the company is liable for its entrepreneurial obligations regardless its fault, whereas its executives may be recognised liable for the damages caused to the company, only if they have acted intentionally.
} 
between him and the company, if his acts have not been approved afterwards, or if he has concealed or falsified the information related to the made transaction, or left it unapproved, or has not submitted to the company the documents related to the transaction, or has made obviously disadvantageous or invalid transaction. ${ }^{82}$

In turn, the director is not regarded as acted reasonably, if he has not taken into account in his decision the essential information, or has not followed the approval procedure related to the transaction. Furthermore, attention must be paid to that in the case the action of the director has caused damages, the approval of it at the collective executive body of the company, or by the participants (shareholders) as well as the following the instructions of them does not release the director from the liability for damages, since the fiduciary duties concern him personally, and he bears the independent liability for damages.

The requirements to act reasonably that concern the company director follow in Russian legal as practice as criteria the model of behaviour of an average director, but in concrete cases the requirements could be higher of lower than such standard, taking, however, into account, that the commercial review of the director's acts is not under the court's competence. According to the opinion of the Russian Constitutional Court of 2004, the circle of control of the court includes to secure the protection of the rights and freedom of the shareholders but not to evaluate the economic expediency of the decisions of the governing bodies of the company that enjoy the independence and large discretionary power in their decision-making concerning the commercial activities of the company.

The plaintiff must prove the facts showing that the company body has acted (or unperformed its duties) fraudulently and/or unreasonably, and it has resulted in negative consequences for the company. In the event the plaintiff succeeds, through the reference to that the company body acted fraudulently and/or unreasonably, in proving that it caused damages to the company, the company body ought to, in order to avoid the liability, prove that the damages have been caused due to the reasons that are outside of his control. The court may order the company body that left its duties unperformed or performed them fraudulently to prove that it did not violated its duty to the company to act in good faith and reasonably.

\section{Rights to Claim of the Participants}

According to the Civil Code ${ }^{83}$, the participant has the right to demand, on behalf of the company through using his representative power in accordance with the Civil Code ${ }^{84}$ compensation for the losses caused by the representative (the executive or the persons in a dominant position) to the corporation ${ }^{85}$. The

\footnotetext{
${ }^{82}$ As the cases when the director of the company has been condemned to compensate the damages, Russian legal practice knows the cases, where the payment has been executed in default of any contract or under the nonexistent contract, where the assets of the company has been used improperly, where the debt has been forgiven without a legal ground or where the trade mark has been violated by fault. For more on the subject see, for instance, Stepanov (2018) at 2.

${ }^{83}$ Russian Civil Code, art. 65.

${ }^{84}$ Ibid. at art.182.1.

${ }^{85} \mathrm{Ibid}$. at art. 53.1.
} 
participant must take reasonable measures for notifying in advance the other participants and, if necessary, the corporation itself of his intend to challenge the decision of the company. The participants who have not joined the claim are not to have the right to present the same demand s, unless the court approves the grounds for this. ${ }^{86}$.

Among the rights of a participant of the company (and partnership), there is, according to the Civil Code $^{87}$, the right to demand in judicial procedure another participant be expelled with the compensation of actual value of his share, if such a participant has caused by his actions (omissions) substantial harm to the company. Or otherwise substantially disturbs its activities and the attainment of the objectives for which it has been formed, including the gross violation of his duties established by the law or the constitutive documents of the company. The waiver of that right or restrictions on it is null and void.

\section{Liability in the Case of Reorganisation}

Compensation for damages issue may arise in respect of the reorganisation of company, where the claims of the debtor are left unperformed, and the sufficient security for the performance of the obligation has not been offered. In that case, in addition to the juristic persons formed as a result of the reorganisation, their collective bodies members and representatives as well as the persons who have real power to decide on the actions of the company are solitarily liable for the damages caused by their actions. ${ }^{88}$

Also, in the event that a court recognises, in accordance with the Civil Code ${ }^{89}$, the decision on the company reorganisation as invalid, the question of compensation for damages may arise. In that case the reorganised juristic persons as well as the persons, who fraudulently promoted the invalidated decision, are solidarily liable to a participant of the reorganised company, who voted against such a decision or did not participate in voting, as well as to the debtors of the reorganised juristic person.

In respect of the cases where the partnership is transformed into a company, the Civil Code provides a special rule ${ }^{90}$ that concerns the liability of general partners. According to it, each general partner, who has become the participant (the shareholder) of the company, is to be subsidiarily liable with his whole

\footnotetext{
${ }^{86}$ The participant has also the right to demand on behalf of the company (or join the joint claim), according to the Civil Code, that a transaction of the company is recognised as invalid, because of the breach of the conditions imposed upon the exercise of the representative power or on the grounds established in the corporate law provisions, as well as demand the application of the consequences of the invalidity of a transaction. The invalidity claim, provided by the article 174 of the Civil Code could be regarded as an alternative to the compensation demand $\mathrm{s}$ on the grounds established by the article $53^{1}$ of the Civil Code. Taking, however, into account that, in the event the decision of the company is recognised as invalid, the restitution rules related to this are to be applied and they might have, in principle, the consequences even for third persons, the imposition of the compensation for damages on the executives seems for law politics reasons better solution.

${ }^{87}$ Russian Civil Code, art. 67.1.

${ }^{88}$ Ibid. at art.60.3.

${ }^{89} \mathrm{Ibid}$. at art. $60^{1}$.

${ }^{90}$ Ibid. at art. 68.2.
} 
property in the course of two years for the obligations that passed to the company from the partnership; this liability will remain in force even in the event of transfer of the shares.

\section{Obligation Law Liability and its Forms}

The civil regulation of the liability related to the company activities, in addition to the corporate law norms, includes the obligation law norms ${ }^{91}$ where the contract law provisions that are to be applied to the contract that the company conclude with the other parties, as well as the provisions that regulate the noncontractual liability are important. Contract liability is usually grounded on the contract that is concluded between its parties and realises in the event of breach of its obligations. The definition of its conditions is not strictly bounded to the legal provisions, and contracting parties may establish liability also for the breaches that are not provided with legal consequences. Furthermore, in some cases the contractual parties may agree on the increase or reduce of the liability established by the law.

Contrary to that, the non-contractual liability is applicable only in the cases established by the law and in accordance with its imperative rules. Such liability or tort liability arises as the consequence of the illegal act of one person against another, and is applicable also in the cases where the breach of the obligation results in the damages to life and health of the injured person ${ }^{92}$, for instance, if a traveller is injured in a road accident. ${ }^{93}$

In addition to the tort liability, the non-contractual liability covers other cases of civil law liability that are based on other grounds than contract, including the unjust enrichment. In Russian civil law, the liability forms are distinguished, and as a general rule, it is regarded that the injured person has no right to choose what claim he presents to the same person.

\section{Compensation for Damages}

Compensation for damages is a general form of liability related to contract obligations. According to the Civil Code ${ }^{94}$, a debtor is obliged to compensate the creditor for the damages caused by nonperformance or improper performance of the obligations. In Russian law, compensation for damages may be used in any case of breach of law ${ }^{95}$, unless otherwise provided by the law or a contract, and it is distinguished from the other forms of liability that these are applicable only in the cases expressly provided for by the law or a contract. Moreover, the right of

\footnotetext{
${ }^{91}$ For more on the subject see Orlov (2011) at 207-209.

${ }^{92}$ Russian Civil Code, art. 1084.

${ }^{93}$ In Russian civil law, the illegality of the act that caused the damages, the causal connection between the act and damages as well as the fault of the violator are regarded as general requirements for the emergence of civil liability also in the cases of tort liability.

${ }^{94}$ Russian Civil Code, art. 393.1.

${ }^{95}$ According to the general rule of the Article 15.1 of the Civil Code on compensation for damages, a person whose right has been violated may demand compensation for the damages caused to him.
} 
the creditor for compensation for damages is established by the Civil Code as independent from other ways of protecting violated rights, provided by the law or a contract for the cases of nonperformance or improper performance of obligation, unless otherwise established by the law.

The general rule is, under the rules of the Civil Code on general liability for damages, that the damages are to be compensated in full ${ }^{96}$. Exceptionally, the law or a contract may provide limited liability or limit the right to full compensation for damages ${ }^{97}$. The application of the principle of full compensation to contract obligations means that, as a result of compensation for damages, the creditor shall be in the position that he would have, if an obligation had been property performed $^{98}$.

The damages to be compensated mean, firstly, covering the real, actual damages or the compensatory damages ${ }^{99}$. The expenses which the creditor must pay to restore the violated right are to be taken into account ${ }^{100}$. Secondly, the loss or harm to the property is to be compensated. Full compensation also includes covering the undeceived profits or the lost profit which the injured party would have received under the usual conditions of civil commerce, if his right had not been violated; in such a case also the measures taken by the creditor to receive the profit and the preparations made for this purpose are to be taken into account ${ }^{101}$. But if the violator has received income as a result of the violation, the injured party is entitled to demand compensation for lost profit in an amount not less than such income $^{102}$. It is also possible that changes in prices shall be taken into account. According to the Civil Code, the prices shall be taken into account which existed at the place where the obligation was to be performed on the date of voluntary satisfaction by the debtor of the claim of the creditor, and in default of this, on the day of filing the suit, and proceeding from the circumstances, a court may satisfy a claim taking into account the prices existing on the day of making decision. ${ }^{103}$

The amount of losses to be compensated is to be established with a reasonable degree of certainty. A court may not deny satisfaction of the creditor's claim to compensate for the losses caused by failure to perform or improper performance of an obligation solely on the grounds that the amount of losses cannot be estimated with a reasonable degree of certainty. In such a case, the amount of the losses to be compensated ought to be estimated by a court taking into account all the facts related to a case and following the principles of equity and proportionality of

\footnotetext{
${ }^{96}$ Ibid. at arts. 15.1 and 1064.1.

${ }^{97}$ The cases when civil liability is restricted concern, for instance, the carrier's and insurer's obligations. Russian civil law knows also cases of enlarged liability; it is purposed, for instance, to protect consumers.

${ }^{98} \mathrm{Ibid}$. at art. 393.2.

${ }^{99}$ They include only direct damages which are the direct and unavoidable consequence of the violation of the obligation, but not consequential damages...

${ }^{100}$ Russian Civil Code, art. 15.2.

${ }^{101}$ Ibid. at art. 393.4.

${ }^{102} \mathrm{Ibid}$. at art. 15.2.

${ }^{103}$ Ibid. at art. 393.3.
} 
liability to the occurred breach of obligation ${ }^{104}$. Also, abstract damages are compensable in accordance with the new provisions of the Civil Code ${ }^{105}$.

An exception from the general obligation law rule on liability is provided for obligations connected with entrepreneurship. The specific feature of the liability for violation of contractual obligations connected with the entrepreneurial activities is that its task in cases of the disturbance in performance of the entrepreneur's obligations is to transfer the risks to the party violating the contract, which is reflected in the strict liability for this. Unless otherwise provided by the law or a contract ${ }^{106}$, a person violating the obligation of performance connected with entrepreneurship is to bear liability, according to the special (exculpation) rule of the Civil Code on the grounds of obligation law liability ${ }^{107}$, unless he proves that proper performance has been impossible because of force majeure, meaning extraordinary and unavoidable circumstances. To such circumstances shall not, however, be referred, for instance, violations of obligations on the part of the debtor's counter-agents, the absence on the market of goods indispensable for the performance or the absence of the necessary means at the debtor's disposal ${ }^{108}$. Thus, a contract violator must prove the absolute impossibility of contractual performance. It means also that he ought to prove that he had not contributed to the emergence of force majeure, that he had, with the degree of care and caution required by the nature of the obligation and commercial practice, taken all measures for the proper performance: otherwise he will not be released from liability ${ }^{109}$. In the event the impossibility of performance is caused faulty by the creditor or debtor, the rules on fault liability are to be applied.

\section{Liquidated Damages}

Liability for breach of contract in Russian law comprehends not only compensation for damages but also liquidated damages that a contract violator is to pay his counterparty in accordance with the law or a contract. Liquidated damages play a double role in Russian law: on the one hand, it is a security measure for performance of an obligation ${ }^{110}$, and on the other hand, a form of contract liability that is to be realised in the case of breach of contract ${ }^{111}$. As a form of contract liability liquidated damages are subject to the provisions of the Civil Code on damages and liquidated damages. ${ }^{112}$

\footnotetext{
${ }^{104}$ Modern Russian civil law is also acquainted with the concept of foreseeability of damages in contract, in accordance to which the unforeseen damages are not subject to compensation.

${ }^{105}$ See Russian Civil Code, art. 393.5 as amended by the law no. 42-FZ of 2015.

${ }^{106}$ For instance, the liability of an agricultural producer for the breach of contract presupposes under the Article 53 of the Civil Code his fault. The similar liability is provided in the rules of the Article 547.2 of the Civil Code on supply of energy.

${ }^{107}$ Russian Civil Code, art. 401.3.

${ }^{108} \mathrm{Ibid}$.

${ }^{109}$ Ibid.

${ }^{110}$ See Ibid. at arts. 330-333.

${ }^{111}$ See Ibid. at arts. 394 and 396.

${ }^{112}$ Ibid. at art. 394.
} 
As liquidated damages (penalty, fine) are recognised in the Civil Code the sum of money, defined by the law or contract, which the debtor is obliged to pay to the creditor in case if he will not perform his obligation in accordance with the contract $^{113}$, including nonperformance, improper performance and a delay in performance. Liquidated damages could be defined as a destined sum (single payment) or an interest that will be counted according to the duration of the violation of the contract (for instance, daily) or its value. By the claim for the liquidated damages, the creditor shall not be obliged to prove that the damage has actually been inflicted upon him; the fact of violation is a sufficient ground for compensation. And in respect of obligations connected with entrepreneurship, it is unnecessary to prove the fault of the debtor, since the liability in the form of liquidated damages is independent from the fault of the contract violator. Thus, in the use of the creditor, liquidated damages are simple measure to get compensation from the debtor for the damages caused by his failure to perform or improper performance of an obligation. The only ground for the application of liquidated damages is the breach of the rules concerning the obligations, provided by the law or a contract, or following from a custom. In general, the payment of the liquidated damages (as well as the compensation of the damages) shall absolve the debtor from the performance of the obligation in kind in the case of non-performance, contrary to case of the improper performance, unless otherwise provided by the law or a contract. However, the creditor shall not have the right to claim the payment of the damages if the debtor is not liable for the non-performance or improper performance of the obligation. ${ }^{114}$

Liquidated damages are clearly a form of civil liability. But, although liquidated damages as a form of contract law liability is related to the concept of compensation for damages, they are, however, significantly different. The compensation for damages is distinguished from the liquidated damages above all in that in the case of compensation for damages:

1) damages are to be compensated, only if they are really incurred,

2) the plaintiff must prove not only the amount of the compensatory damages but also that he has taken all possible measures to avoid damages, and that

3 ) it is impossible to uncover all damages at the moment of the contract breach, and the amount of the compensatory damages is usually clarified the court proceedings.

Contrary to that, it is characteristic for liquidated damages that:

a) The amount of the compensation for damages for the contract breach is defined in advance, wherefore the contracting parties know it since the conclusion of their contract,

b) Liquidated damages are compensable simply on the ground that the obligation breach has occurred, when it is not necessary for the debtor to prove

\footnotetext{
${ }^{113}$ Ibid. at arts. 330.1 .

${ }^{114}$ Ibid. at art. 300.
} 
that the damages has been caused to him, nor even indicate the amount of damages 115 , and

c) The contracting parties may formulate freely the condition on liquidated damages (except for the statutory liquidated damages), which concerns the amount of the liquidated damages and the method of their calculating, as well as the proportion of the liquidated damages to the caused damage.

The liquidated damages and compensation for damages may be presented concurrently. According to the general rules, the liquidated damages cover the compensation for damages. In the provisions of the Civil Code that regulate the relation between the compensation for damages and the liquidated damages ${ }^{116}$, it is expressly provided that if liquidated damages are provided for nonperformance or improper performance of an obligation, damages are to be compensated in the part not covered by the liquidated damages; those are so-called compensatory liquidated damages ${ }^{117}$. This rule is, however, dispositive, and the law or a contract may provide otherwise. Firstly, the law or a contract may provide, according to the Civil Code that only the liquidated damages but not the compensatory damages are to be recovered; the question is of so-called exclusive liquidated damages. Secondly, the law or a contract may provide penal liquidated damages, in which case the compensation for damages is covered in full amount above the liquidated damages. Thirdly, the law or a contract may contain the provision that either liquidated damages or compensation for damages are, at the choice of the debtor, recoverable.

The duty to pay liquidated damages is based in Russian law on the same grounds as in the case of compensation for damages liability, and this means that the debtor is not entitled to demand liquidated damages, if the creditor is not liable for the obligation breach. But in the event of the breach of the contract obligations connected with enterprise activities, the person who has left his obligation unperformed or improperly performed it, is, according to the Civil Code ${ }^{118}$, liable, unless he proves that the proper performance became impossible due to force majeure, that is, extraordinary circumstances unavoidable in the given situationunless the law or a contract provides otherwise.

According to the Civil Code ${ }^{119}$, the reduction of liquidated damages is possible in Russia, and the rules on it concern not only the statutory but also the contractual liquidated damages. According to the rules, only a court has power to reduce liquidated damages, and only in the event, that liquidated damages subject to payment are clearly disproportional to the consequences of the obligation breach. But if the obligation violator is the person who is practicing enterprise activities, a court has the right to reduce liquidated damages only on the demand of the creditor ${ }^{120}$. Furthermore, if in that case the liquidated damages are determined

\footnotetext{
${ }^{115}$ On the contrary, it is within the interest of the creditor to prove the small amount of damages or even their absence for the court could reduce the amount of liquidated damages in accordance with the Article 333 of the Civil Code.

${ }^{116}$ Ibid. at art. 394.1.

${ }^{117} \mathrm{Ibid}$. at art. 394.1.

${ }^{118} \mathrm{Ibid}$. at art. 401.

${ }^{119} \mathrm{Ibid}$. at art. 333.

${ }^{120} \mathrm{Ibid}$. at art. 333.1 .
} 
by the contract, their reduction is possible only if it is proven, that their payment may result in the debtor's unjust enrichment. However, it is important that the rules on reduction of liquidated damages does not concern the cases, where the creditor has the right to reduce the amount of his liability under the rules on joint liability $^{121}$, and where the debtor has the right to demand compensation for damages in accordance with the rules of the Civil Code on the compensatory damages and liquidated damages ${ }^{122}$.

\section{Indemnity}

The Civil Code contains at present the rules on the compensation for the losses resulting from the Occurrence of the Circumstances Defined in the Contract, that is, the indemnity clause. According to the rules, the obligation parties, who are practicing enterprise activities, may provide in their agreement the duty of either party to compensate for the property losses of the other party resulting from the occurrence of the circumstances determined in such agreement which are not connected with the obligation violation by this party, including the losses caused by the impossibility to perform the obligation, the claims raised by third persons or public authorities against the party or a third person indicated in the agreement etc.). ${ }^{123}$ The agreement may define the amount of compensation, which may not be reduced by a court, except if it is proved that a party has contributed intentionally to the losses. The indemnity losses are recoverable even in the event that the contract is recognised as not concluded or invalid, unless otherwise provided by the agreement. In turn, if the losses have arisen due to the illegal acts of a third person, the creditor's claims against this third person are to be transferred to the party that has compensated for the losses.

\section{Precontractual Liability (negative contract interest)}

Russian contract law is also acquainted with precontractual liability and negative contract interest related to it, the general rules on which are introduced into the Civil Code in $2015^{124}$. The provisions of the Civil Code that regulate contracting negotiations ${ }^{125}$, where precontractual liability may arise, include the rules on fault in contracting (culpa in contrahendo), according to which the party that fraudulently uses or interrupts contracting negotiations is obliged to compensate the caused damages or negative contract interest to the counterparty. ${ }^{126}$ The negative contract interest stands primarily for the expenditures related to the contract negotiations, where also the lost opportunities to make a profitable contract may be compensated. The rules on fault in contracting are applicable regardless whether, as the result of negotiations, the contract has been concluded

\footnotetext{
${ }^{121}$ Ibid. at art. 404.

${ }^{122}$ Ibid. at art. 394.

${ }^{123} \mathrm{Ibid}$. at art. 406.1 .

${ }^{124} \mathrm{By}$ the law no. $42-\mathrm{FZ}$ of 2015.

${ }^{125}$ Ibid. at art. 434.

${ }^{126}$ Ibid. at art. 434.3.
} 
or not ${ }^{127}$. On the other hand, the application of the rules on fault in contracting does not prevent that the relations arisen in the contracting become subject to the rules on tort liability.

\section{Conclusion}

Russian law now contains well developed rules that regulate civil law liability and also corporate liability. In particular, the liability of the corporate executives to the company is subject to sophisticated rules, whereas the corporate liability to other persons than the company and especially the company's liability to its participants (shareholders) and outside persons as well as the liability of shareholder of the company to its debtors are not, however, recognised in Russian corporate law. The regulation of corporate activities has been executed in Russia primarily by legislative norms, and it shows their dominance in Russian law. On the other hand, the use of value concepts and value norms in modern Russian civil law indicates its development towards the increase of judicial discretion and consequently the recognition of the significance of judicial practice as a source of law.

\section{References}

Borisov, A.N. (2017). 'Комментарий к Федеральному закону от 26 декабря 1995 г. № 208-Ф3 «Об акционерных обществах»' [Commentary on Federal Law No. 208-FZ of December 26, 1995 "On Joint Stock Companies" (itemised; third edition, revised and supplemented). - "Business yard" http://base.garant.ru/77776224

Grudtsyna, L.J. (2008). Гражданское право России [Civil Law of Russia]. Moscow.

Orlov, V. (2011). Introduction to Business Law in Russia. London: Routledge. https://doi. org/10.4324/9781315589688

Orlov, V. (2015). 'Alternatives to capital oriented corporations under Russian law' in Hillman, R.W. \& Loewenstein, M.J. (Eds.) Research Handbook on Partnerships, LLCs and Alternative Forms of Business Organizations, at pp. 412-428.

Stepanov, D. (2018). Ответственность директора перед корпорацией за причиненные ей убытки в судебной практике. [Liability of a director to the corporation for damages caused to it in the judicial practice]. Statut, Moscow.

Stepanov, S.A. (ed.) (2016). Гражданское право [Civil Law]. Moscow.

Tekutyev, D.I (2018). Правовой механизм повышения эффективности деятельности членов органов управления хозяйственных обществ [Legal mechanism of increasing of effectiveness of activities of members of the governing bodies of economic societies]. J.C. Diss. Moscow State University.

Trofimov, D.I. (2018). 'Правовая природа и характерные особенности юридической ответственности в корпоративных отношениях' [Legal nature and characteristic features of liability in the corporate relations]' in Molodoj utshenyj [Young scholar] 23:141-143.

Tselovalnikova, I.Y. (2018). 'Гражданско-правовая ответственность участников корпоративных отношений [Civil Liability of Participants of Corporate Relations]'

${ }^{127}$ Ibid. at art. 434.7 . 
in Актуальные проблемы российского права [Actual Problems of Russian Law] 11:60-67.

Yarkovoy, S.V. (2017) 'Законность административной правоприменительной деятельности в Российской Федерацииш' [Legality of administrative law practice in Russian Federation]' in Вестник Омской юридической академии [Bulletin of the Omsk law academy] 14(4):82-89. 
